\title{
High prevalence of neuropathic pain in the hand of patients with traumatic brachial plexus injury: a cross-sectional study
}

\author{
Alta prevalência de dor neuropática em sujeitos com lesão traumática do plexo braquial: \\ um estudo de corte transversal
}

\author{
Marcus V. B. Santana,2, Mauro T. Bina ${ }^{3}$, Matheus G. Paz³, Scheila N. Santos 3 , Manoel J. Teixeira4, \\ Irina Raicher ${ }^{4}$, José V. Martins 5 , Daniel C. Araujo Andrade ${ }^{4}$, Abrahão F. Baptista ${ }^{1}$
}

\begin{abstract}
Objective: To describe the pain profile of patients with traumatic brachial plexus injury. Methods: We enrolled 65 patients with traumatic brachial plexus injury. The Douleur Neuropathique 4 questionnaire was used to classify pain and the SF-36 was used to evaluate quality of life. Results: The patients with traumatic brachial plexus injury were predominantly young male victims of motorcycle accidents. Pain was present in $75.4 \%$ of the individuals and $79 \%$ presented with neuropathic pain, mostly located in the hands (30.41\%). The use of auxiliary devices ( $p=0.05)$ and marital status ( $p=0.03$ ) were both independent predictors of pain. Pain also impacted negatively on the quality of life $(p=0.001)$. Conclusions: Pain is frequent in patients with traumatic brachial plexus injury. Despite the peripheral nervous system injury, nociceptive pain is not unusual. Pain evaluation, including validated instruments, is essential to guide optimal clinical management of patients with the condition.
\end{abstract}

Keywords: brachial plexus; nociceptive pain; pain; peripheral nerve injuries.

\section{RESUMO}

Objetivo: Descrever o perfil de dor de sujeitos com lesão traumática do plexo braquial. Métodos: Nós incluímos 65 indivíduos com lesão traumática do plexo braquial. O Douleur Neuropathique 4 foi usado para classificar a dor e o SF-36 foi usado para avaliar a qualidade de vida. Resultados: Sujeitos com lesão traumática do plexo braquial eram em sua maioria homens jovens, vítimas de acidentes motociclísticos. A dor esteve presete em $75.4 \%$ dos indivíduos e $79 \%$ deles apresentaram dor neuropática, mais frequentemente localizada nas mãos (30.41\%). O uso de dispositivos auxiliares $(p=0.05)$ e o estado civil foram, ambos, preditores independentes de dor. A dor ainda impactou negativamente da qualidade de vida $(p=0.001)$. Conclusões: A dor é frequente em sujeitos com lesão traumática do plexo braquial. Apesar de envolver uma lesão do sistema nervoso a dor nociceptiva não é infrequente. A avaliação da dor, incluindo instrumentos validados, é essencial para direcionar as condutas clínicas de sujeitos com esta condição.

Palavras-chave: plexo braquial; dor nociceptiva; dor; traumatismos dos nervos periféricos.

Traumatic brachial plexus injury (TBPI) is a highly disabling condition, commonly seen in young men. This injury leads to difficulties in performing upper limb movements, sensory changes, emotional disturbances and pain ${ }^{1,2,3}$. The prevalence of pain in TBPI varies between $24 \%$ and $95 \%$ and can occur immediately after the injury or several days or months after the traumatic event ${ }^{3}$. Over $50 \%$ of individuals with TBPI experience pain ${ }^{4,5,6,7,8,9,10}$, which is generally described as shooting, smashing, burning or electric shocks ${ }^{11,12}$.

The origin of the pain is not clearly established, and this may be a confounding factor for treatment. Furthermore, it is important to distinguish nociceptive from neuropathic pain. The nervous system lesion may explain the manifestation of neuropathic pain, but injuries to musculoskeletal

1 Universidade Federal da Bahia, Faculdade de Medicina, Programa de Graduação em Medicina e Saúde, Salvador BA, Brasil;

${ }^{2}$ Faculdade de Medicina Baiana e Saúde Pública, Salvador BA, Brasil;

${ }^{3}$ Universidade Federal da Bahia, Faculdade de Medicina, Salvador BA, Brasil;

${ }^{4}$ Universidade de São Paulo, Faculdade de Medicina, Departamento de Neurologia, São Paulo SP, Brasil;

5Universidade Federal do Rio de Janeiro, Instituto Deolindo Couto de Neurologia, Rio de Janeiro RJ, Brasil.

Correspondence: Marcus V. B. Santana; Universidade Federal da Bahia, Instituto de Ciências da Saúde; Av. Reitor Miguel Calmon, s/n / sala 306; 40110-902 Salvador BA, Brasil; E-mail: marcusba@hotmail.com

Conflict of interest: There is no conflict of interest to declare.

Received 14 April 2016; Received in final form 20 July 2016; Accepted 16 August 2016. 
structures, such as bones and soft tissues, could explain the onset of nociceptive pain ${ }^{5,13}$. Although some studies classify the pain present in TBPI according to well-established criteria $^{5,9}$, many merely assume that pain is neuropathic given the presence of the brachial plexus injury ${ }^{6,7}$. Furthermore, most studies on pain in TBPI were not designed to describe the painful profile in this condition ${ }^{7,8}$.

Giving the lack of detailed information about the pain profile in individuals with traumatic brachial plexus injury, this study had two objectives: a) to classify the type of pain as neuropathic or nociceptive; and b) to describe associations among pain characteristics, demographic data, quality of life, and symptoms of anxiety/depression.

\section{METHODS}

This cross-sectional study was conducted between June 2011 and September 2013 in three Brazilian referral centers. We included patients with TBPI, diagnosed by a neurologist. Exclusion criteria were: (1) Patients with psychiatric disorders or cognitive impairment that would prevent accurate answers to the questions of the study; (2) Individuals who were submitted to surgeries on the central nervous system; (3) Individuals with a history of non-traumatic diseases of the peripheral nervous system; (4) Individuals with a history of cervical spine disease, thoracic outlet syndrome and prior neuropathy in the affected arm; (5) Participants presenting with peripheral nerve injuries in both upper limbs.

\section{Outcomes}

Pain location was evaluated using a body map, and its intensity with a 0-100 Visual Analog Scale classified as low (below 25), moderate (between 25 and 75) and high intensity (up to 75). Sociodemographic data and information related to pain duration were also collected. The first seven questions of the Brazilian version of the Douleur Neuropathique 4 questionnaire ${ }^{14}$ were used to classify pain as neuropathic or nociceptive. Scores over three were considered as neuropathic pain ${ }^{15}$. Anxiety and depression were evaluated with the Hospital Anxiety and Depression Scale, and quality of life by the 36-item Short Form Health Survey (SF-36) questionnaire. The Brazilian Criteria for Market Research was used to determine social class. The sample size calculation was based on a previous study ${ }^{5}$ showing that the prevalence of neuropathic pain in patients with TBPI was $67 \%$, with an absolute estimation accuracy of $15 \%$ and alpha value of $5 \%$. The required number was 40 patients, which was expanded to 65 in view of the differences between the conditions in the three different pain centers.

To avoid possible biases, the following precautions were taken: the sample size calculation was based on a previous study ${ }^{5}$; the evaluations were conducted by a trained team and all of them were standardized; all assessment instruments were validated and had good levels of reliability in their implementation; participants who needed assistance with communication were excluded; the study followed the recommendations of the STROBE Guideline ${ }^{16}$.

\section{Statistical analysis}

The descriptive analysis was carried out for the sociodemographic variables, prevalence, type, location and temporal characteristics of pain. To assess the impact of those variables on pain we used multivariate logistic regression. Univariate logistic regression models were adjusted for all the explanatory variables. The variables with a significance level of $\mathrm{p}<0.20$ were entered into a single model, and an automatic stepwise selection procedure was then performed, with only those variables with $\mathrm{p}<0.05$ remaining in the model. The Hosmer-Lemeshow test was used to verify that the regression model was appropriate. To compare the quality of life of patients with and without pain, the t-test for independent samples was used, with $5 \%$ significance level. The Fisher's exact test was used to assess the association between pain and anxiety and between pain and depression. The G-test was used to evaluate the association between pain and the frequency of physiotherapy, assistive device usage, level of injury and surgery.

\section{Participants and ethical considerations}

This study was approved by the Institutional Review Board from Climério de Oliveira Maternity Hospital, number 022/11 (blinded). All patients gave written informed consent to participate. This study included a total of 65 individuals with TBPI. Participants were mostly young males, single, belonging to the middle class, had completed secondary or higher education and were unemployed (Table 1).

\section{RESULTS}

The majority of patients were right handed ( $n=36,44.6 \%)$, the time from injury was $78 \pm 88$ week and the time between injury and surgery was $29 \pm 40$ weeks. The most common cause of trauma was motorcycle accidents $(n=47,73.4 \%)$, followed by automobile accidents $(n=7,10.9 \%)$. The remaining causes included being run over, falling from a height, occupational accidents, electric shock, vertical impact injury and others. Individuals referred had movement limitations as the main cause of discomfort ( $\mathrm{n}=35,53.8 \%$ ), followed by pain ( $n=20,30.8 \%)$. Other problems, such as difficulty in finding a job or not working, tingling or numbness, aesthetics, and paresis were less common. The main associated injuries, measured by the number of events that occurred, were fracture of long bones ( $n=23,36.9 \%)$, head injury ( $n=8,12.1 \%)$, loss of consciousness $(n=6,9 \%)$, and luxation of a lower limb extremity $(n=6,7.5 \%)$. The other less frequent events included vertebral fracture, Claude-Bernard-Horner syndrome, coma, burns, 
fracture of facial bones, vascular injury, luxation of an upper limb extremity/ligament injury, cardiovascular arrest, fracture of lower limb extremity bones, and pulmonary injury.

The prevalence of pain was $75.4 \%(n=49)$, and neuropathic pain appeared in $79.2 \%(n=38)$ of patients. Of these, 32 participants presented with associated injuries, the most common being a fracture of long bones (23 times, 36.9\%). Movement limitations and pain were the most reported complaints (Table 1). Data were missed in a small proportion due to religion (1.5\%), marital status (1.5\%), educational degree (1.5\%), occupation (3\%) and trauma etiology (1.5\%),

Of the 65 test patients, 48 patients reported 217 locations of pain, and the most cited sites were the hands $(\mathrm{n}=66,30.41 \%)$, followed by the forearm $(\mathrm{n}=52,23.96 \%)$. The chest and shoulder region $(\mathrm{n}=42,19.35 \%)$ and arms ( $\mathrm{n}=38,17.51 \%$ ) showed similar frequencies. The neck and head were the least cited $(n=19,8.76 \%)$ (Figure 1). Data was missing in one participant.

Table 1. Socio-demographic data of patients with traumatic brachial plexus injury $(n=65)$.

\begin{tabular}{|c|c|}
\hline Variables & $\mathrm{n}(\%$ Mean/SD) \\
\hline \multicolumn{2}{|l|}{ Gender } \\
\hline Male & $58(89,2)$ \\
\hline Age & $30 \pm 11$ \\
\hline \multicolumn{2}{|l|}{ Marital status } \\
\hline Single & $37(57.8)$ \\
\hline Married/ Divorced & $27(42.2)$ \\
\hline \multicolumn{2}{|l|}{ Educational degree } \\
\hline$\leq 6$ years of study & $2(3.1)$ \\
\hline$\leq 7$ years of study & $9(14.1)$ \\
\hline$\leq 11$ years of study & $14(21.9)$ \\
\hline$\leq 14$ years of study & $36(56.2)$ \\
\hline$\leq 19$ years of study & $3(4.7)$ \\
\hline \multicolumn{2}{|l|}{ Occupation } \\
\hline No occupation/ Retired/ Unemployed & $10(16.1)$ \\
\hline Away from work & $44(71)$ \\
\hline Employed & $8(12.9)$ \\
\hline \multicolumn{2}{|l|}{ Social class } \\
\hline Middle class & $45(69.2)$ \\
\hline Lower class & $20(30.8)$ \\
\hline \multicolumn{2}{|l|}{ Pain } \\
\hline No & $16(24.6)$ \\
\hline Yes & $49(75.4)$ \\
\hline \multicolumn{2}{|l|}{ Type of pain } \\
\hline Neuropathic pain & $38(79.2)$ \\
\hline Nociceptive pain & $10(20.8)$ \\
\hline Pain intensity (VAS) & $46(33)$ \\
\hline Duration of pain (weeks) & $58(92)$ \\
\hline \multicolumn{2}{|l|}{ Number of pain sites } \\
\hline One site & $13(26.5)$ \\
\hline Two sites & $12(24.5)$ \\
\hline Three sites & $14(28.6)$ \\
\hline Four sites & 8 (16.3) \\
\hline Five sites & $1(2)$ \\
\hline
\end{tabular}

The logistic regression analysis was used to evaluate independent predictors of pain. The variables selected from univariate analysis (Table 2) to compose the multivariate model were marital status, auxiliary device usage and physiotherapy or occupational therapy. In multivariate analysis, auxiliary device usage and marital status were independent predictors of pain. Subjects who were married or divorced had a greater chance of having pain than those who were single $(\mathrm{OR}=4.75$ $(1,09-17,17) ; \mathrm{p}<0.05)$. Patients who used a sling or sling associated with another auxiliary device tended to have pain more regularly than those who did not use these devices $(\mathrm{OR}=4.32$ $(1,00-18,69) ; \mathrm{p}=0.051)$. The model was adequate according to the results of the Hosmer-Lemeshow test $\left(\mathrm{X}^{2}=1.520, \mathrm{p}=0.823\right)$.

Depressive states were found in seven patients $(10.8 \%)$ and anxiety in 20 (30.8\%). Similar results were found when only individuals with pain were evaluated and 17 (34.7\%) patients had states of anxiety and seven presented with depression (14.3\%). There was no association between pain and anxiety $(\mathrm{p}=0.349)$ or depression $(\mathrm{p}=0.182)$. There was an association between pain scores assessed by the Visual Analog Scale and quality of life regarding functional capacity items $(\mathrm{t}=2.138, \mathrm{p}<0.050)$ and pain $(\mathrm{t}=5.594, \mathrm{p}<0.001)$. Participants who did not feel pain regularly presented with higher scores for quality of life than those who presented with chronic pain (Figure 2). No associations were found between the frequency of physiotherapy, auxiliary device use, surgical procedure and pain intensity. Regarding the auxiliary device use, the difference was borderline ( $G=9,272 ; p=0.055)$, with individuals who used a sling or sling associated with another auxiliary device presenting more moderate pain than others. Evaluation of the relationship between these variables and the type of pain showed that individuals with neuropathic pain attended physical therapy more often (Tables 3 and 4).

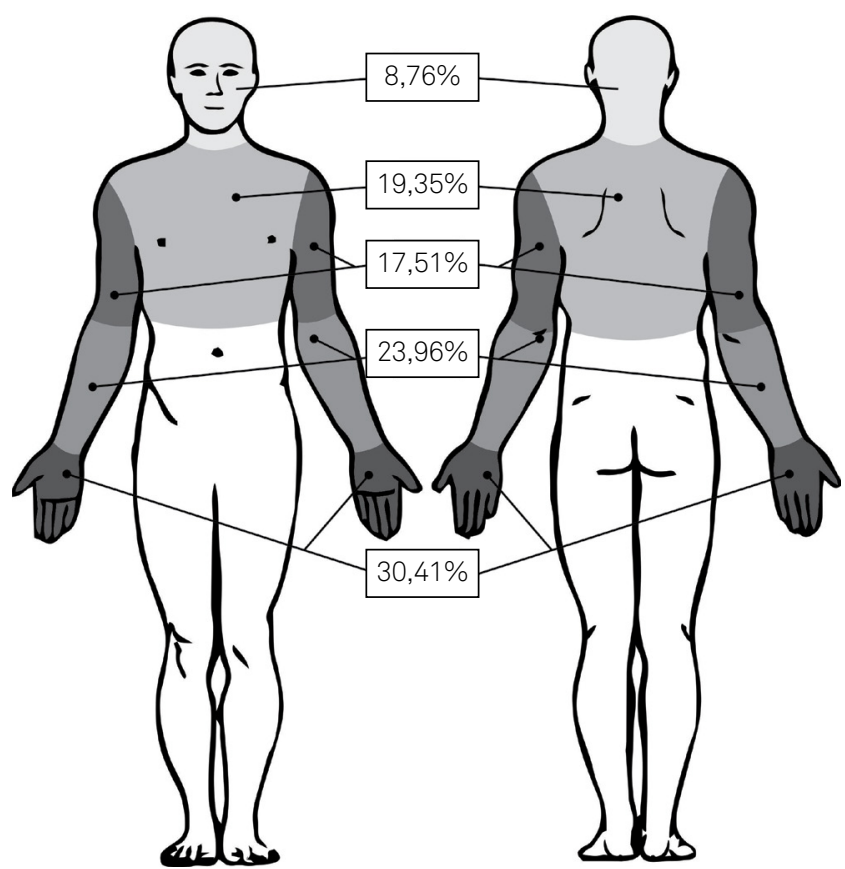

Figure 1. Frequency of pain according to location in the body. 
Table 2. Univariate analysis between pain and socio-demographic data and pain and physiotherapy.

\begin{tabular}{|c|c|c|c|c|}
\hline Variables & OR* Not adjusted (IC95\%) & $p$ & OR* Adjusted (IC95\%) & $\mathrm{p}$ \\
\hline Age & $1.02(0.96-1.08)$ & 0.507 & & \\
\hline \multicolumn{5}{|l|}{ Marital status } \\
\hline Single & 1.00 & - & 1.00 & - \\
\hline Married/divorced & $4.33(1.09-17.17)$ & 0.037 & $4.75(1.12-20.22)$ & 0.035 \\
\hline \multicolumn{5}{|l|}{ Educational degree } \\
\hline High school or college & 1.00 & - & - & - \\
\hline Complete basic education & $1.44(0.34-6.17)$ & 0.623 & - & - \\
\hline Incomplete basic education & $1.77(0.33-9.52)$ & 0.507 & - & - \\
\hline \multicolumn{5}{|l|}{ Occupation } \\
\hline Employed & 1.00 & - & - & - \\
\hline No occupation/retired/unemployed & $2.40(0.29-19.78)$ & 0.419 & - & - \\
\hline Away from work & $1.80(0.37-8.79)$ & 0.468 & - & - \\
\hline \multicolumn{5}{|l|}{ Race } \\
\hline Non white & 1.00 & - & - & - \\
\hline White & $1.00(0.24-4.26)$ & 1.000 & - & - \\
\hline \multicolumn{5}{|l|}{ Auxiliary devices } \\
\hline Neither & 1.00 & - & 1.00 & - \\
\hline Sling or sling associated with other auxiliary devices* & $4.61(1.13-18.92)$ & 0.034 & $4.32(1.00-18.69)$ & 0.051 \\
\hline Others & $1.15(0.27-4.87)$ & 0.854 & $0.89(0.19-4.22)$ & 0.893 \\
\hline \multicolumn{5}{|l|}{ Level of injury } \\
\hline Complete injury & 1.00 & - & - & - \\
\hline Incomplete injury & $1.56(0.25-9.65)$ & 0.631 & - & - \\
\hline \multicolumn{5}{|l|}{ Social class } \\
\hline Middle class & 1.00 & - & - & - \\
\hline Lower class & $1.46(0.41-5.23)$ & 0.566 & - & - \\
\hline \multicolumn{5}{|l|}{ Physiotherapy or occupational therapy* } \\
\hline Yes & 1.00 & - & - & - \\
\hline No & $5.42(0.65-45.18)$ & 0.119 & - & - \\
\hline
\end{tabular}

$\mathrm{OR}^{*}$ : odds ratio; IC: interval confidence.

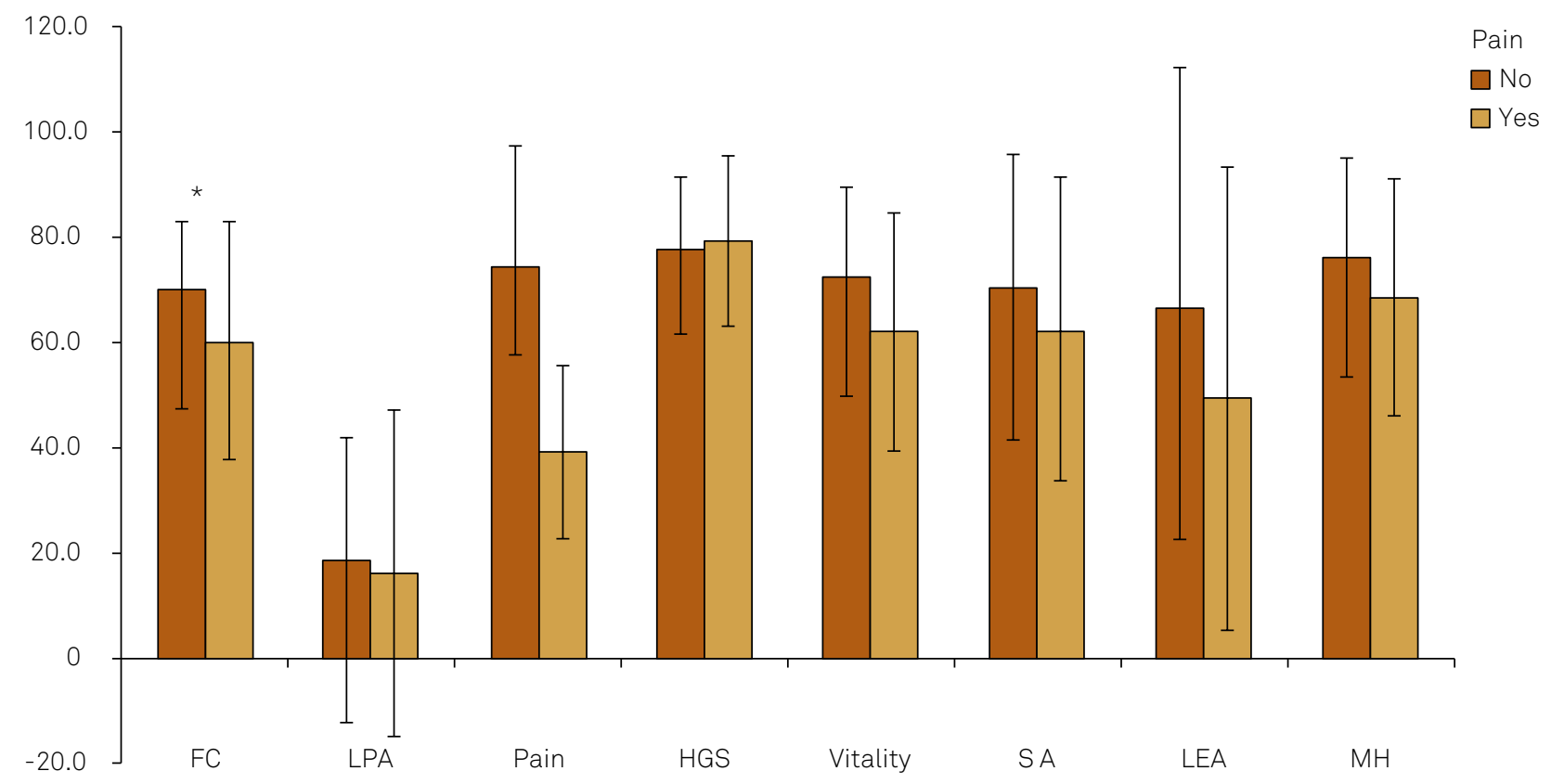

FC: functional capacity; LPA: limitation by physical aspects; HGS: health general status; SA: social aspects; LEA: limitation by emotional aspects; $\mathrm{MH}$ : mental mealth.

Figure 2. Association between quality of life and pain. The results showed significant association between functional capacity and pain. Subjects with pain presented with worse functional capacity results $\left(p=0.038^{*}\right)$. 
Table 3. Association between pain intensity and clinical and surgical variables.

\begin{tabular}{|c|c|c|c|c|c|c|}
\hline \multirow{2}{*}{ Variables } & \multicolumn{3}{|c|}{ VAS* major pain } & \multirow{2}{*}{ Total } & \multirow{2}{*}{ G2 } & \multirow{2}{*}{$\mathrm{p}$} \\
\hline & Low intensity & Moderate intensity & High intensity & & & \\
\hline Frequency of physiotherapy & $5(33.3)$ & $8(53.3)$ & $2(13.3)$ & $15(25.4)$ & 6.527 & - \\
\hline Absent & 5 (33.3) & $8(53.3)$ & $2(13.3)$ & $15(25.4)$ & 6.527 & 0.163 \\
\hline 1-3 times/week & $11(39.3)$ & $6(21.4)$ & $11(39.3)$ & $28(47.5)$ & - & - \\
\hline$>3$ times & $8(50.0)$ & $5(31.3)$ & $3(18.8)$ & $16(27.1)$ & - & - \\
\hline Total & $24(40.7)$ & $19(32.2)$ & $16(27.1)$ & $59(100)$ & -- & \\
\hline \multicolumn{7}{|l|}{ Auxiliary devices } \\
\hline Neither & $10(55.6)$ & $2(11.1)$ & $6(33.3)$ & $18(28.1)$ & 9.272 & 0.055 \\
\hline $\begin{array}{l}\text { Sling or sling associated with } \\
\text { other auxiliary devices** }\end{array}$ & $8(24.2)$ & $16(48.5)$ & $9(27.3)$ & $33(51.6)$ & - & - \\
\hline Others & $6(46.2)$ & $4(30.8)$ & $3(23.1)$ & $13(20.3)$ & - & - \\
\hline Total & $24(37.5)$ & $22(34.4)$ & $18(28.1)$ & $64(100)$ & - & - \\
\hline \multicolumn{7}{|l|}{ Level of injury } \\
\hline Complete injury & 7 (33.3) & 7 (33.3) & 7 (33.3) & $21(63.6)$ & 2.102 & 0.350 \\
\hline Incomplete injury & $2(16.7)$ & 7 (58.3) & $3(25.0)$ & $12(36.4)$ & - & - \\
\hline Total & $9(27.3)$ & $14(42.4)$ & $10(30.3)$ & $33(100)$ & - & - \\
\hline \multicolumn{7}{|l|}{ Surgical procedure } \\
\hline Neurotization & 7 (58.3) & $3(25.0)$ & $2(16.7)$ & 12 (31.6) & 10.470 & 0.234 \\
\hline Grafting & $0(0.0)$ & $1(100)$ & $0(0.0)$ & $1(2.6)$ & - & - \\
\hline Neurotization and grafting & $2(15.4)$ & $5(38.5)$ & $6(46.2)$ & $13(34.2)$ & - & - \\
\hline No surgery & $5(45.5)$ & $4(36.4)$ & $2(18.2)$ & $11(28.9)$ & - & - \\
\hline Neurolysis and neurotization & $0(0.0)$ & $1(100)$ & $0(0.0)$ & $1(2.6)$ & - & - \\
\hline Total & $14(36.8)$ & $14(36.8)$ & $10(26.3)$ & $38(100)$ & - & - \\
\hline
\end{tabular}

Table 4. Association between type of pain and clinical and surgical variables.

\begin{tabular}{|c|c|c|c|c|c|}
\hline \multirow{2}{*}{ Variables } & \multicolumn{2}{|c|}{ DN4 } & \multirow{2}{*}{ Total } & \multirow{2}{*}{ G2 } & \multirow{2}{*}{$\mathrm{p}$} \\
\hline & Nociceptive & Neurophatic & & & \\
\hline \multicolumn{6}{|l|}{ Frequency of physiotherapy (weeks) } \\
\hline Absent & $5(50.0)$ & $9(25.7)$ & $14(31.1)$ & 7.524 & $0.023 *$ \\
\hline $1-3$ times & $5(50.0)$ & $14(40.0)$ & $19(42.2)$ & - & - \\
\hline$>3$ times & $0(0.0)$ & $12(34.3)$ & $12(26.7)$ & - & - \\
\hline Total & $10(22.2)$ & $35(77.8)$ & $45(100)$ & - & - \\
\hline \multicolumn{6}{|l|}{ Auxiliary devices } \\
\hline Neither & $2(20.0)$ & $10(25.0)$ & $12(24.0)$ & 0.602 & 0.740 \\
\hline Sling + Sling and other auxiliary devices & $7(70.0)$ & $23(57.5)$ & $30(60.0)$ & - & - \\
\hline Others & $1(10.0)$ & $7(17.5)$ & $8(16.0)$ & - & - \\
\hline Total & $10(20.0)$ & $40(80.0)$ & $50(100)$ & - & - \\
\hline \multicolumn{6}{|l|}{ Surgical procedure } \\
\hline Neurotization & $2(33.3)$ & $4(16.0)$ & $6(19.4)$ & 5.160 & 0.271 \\
\hline Grafting & $1(16.7)$ & $0(0.0)$ & $1(3.2)$ & - & - \\
\hline Neurotization and grafting & $2(33.3)$ & $11(44.0)$ & $13(41.9)$ & - & - \\
\hline No surgery & $1(16.7)$ & $9(36.0)$ & $10(32.3)$ & - & - \\
\hline Neurolysis and neurotization & $0(0.0)$ & $1(4.0)$ & $1(3.2)$ & - & - \\
\hline Total & $6(19.4)$ & $25(80.6)$ & -100 & - & - \\
\hline
\end{tabular}

DN4: douleur neuropathique 4; G2: G-test.

\section{DISCUSSION}

This study aimed to estimate the prevalence of pain in patients with TBPI, establish location patterns, intensity, temporal behavior and pain scores. Furthermore, we aimed to verify the impact of pain on the quality of life. The prevalence of pain was $75.4 \%$, and the most common type of pain was neuropathic, located in the hand region. The main contribution of this study was to assess patients from three different reference centers, using validated instruments and exploring a range of pain characteristics in these individuals, which has not been described systematically in the literature. There was no association between pain and anxiety or depression, although anxiety is present in approximately one 
third of the patients. Quality of life was associated with pain in items related to pain and functional capacity domains. The characteristics of sex, age, type of accident and extent of injury were similar to other studies evaluating individuals with $\mathrm{TBPI}^{6,7,8,10,17}$

The majority of our patients had completed high school, but they were unemployed. Almost half of them had some associated injury, fractures of long bones being the most common $^{6}$. The socioeconomic profile may explain the choice of more affordable vehicles like the motorcycle. This form of urban transport is mostly used by young men, who are then the main victims of this type of injury. The head is pushed in the opposite direction to the shoulder, stretching the brachial plexus ${ }^{18}$.

In fact, the southeast and northeast regions have the highest number of motorcycles in Brazil (66\%), and the number of accidents related to this type of vehicle is increasing every year, according to the National Department of Transport Infrastructure $^{18}$. In a motorcycle accident, the subject falls, hitting the ground. The Brazilian Government has developed actions to promote traffic safety education, and prevention strategies have gained more attention. The number of deaths related to traffic accidents has reduced and consequently the number of people with injury sequelae has increased after the implementation of laws that established penalties for drunk driving, according to data from Brazilian Government ${ }^{18}$.

The prevalence of pain in these TBPI injuries is usually elevated ${ }^{5,6,8,9,10}$. Only one study found conflicting results ${ }^{7}$. As in our results, the pain usually begins suddenly and is located in the hand ${ }^{1,11,19}$. In clinical practice, it has been observed that in some cases the diagnosis of brachial plexus injury is delayed, possibly because the subject has multiple injuries ${ }^{5,20}$. In this case, movement limitations associated with the characteristics of sudden localized pain in the hand could be indicative of brachial plexus injury ${ }^{19,21}$. The maladaptive plasticity in sensory and motor cortices, with invasion of adjacent regions in the hand representation area may explain this finding. Similar results were reported in patients with phantom limb pain ${ }^{20}$, a condition where there is also denervation of the affected limb.

Many patients described the pain as burning or associated with electric shocks ${ }^{10,11,12}$, consistent with the most common type of pain ${ }^{5,8,9}$. Because it is an injury of the nervous system, it is expected that the majority of patients will present with neuropathic pain. However, nociceptive pain cannot be ruled out. In some previous studies, pain classification has been made through clear diagnostic criteria ${ }^{5,9}$, but in others the criteria have not been specified ${ }^{6,7}$. Adopting ratings without the use of established criteria may under- or overestimate the diagnosis of pain, increase the chance of misguided interventions, and consequently risk therapy failure.

In this study, the independent predictors of pain were the use of a sling with or without auxiliary devices, and marital status. It has been observed that patients with
TBPI continue using the auxiliary device for long periods ${ }^{22}$ - in some cases for more than a year. This behavior may be explained by erroneous beliefs about pain, such as that immobilization may improve pain symptoms. These results suggest that limb restriction can be a detrimental factor. It is possible that this factor is associated with complaints of pain in the hand. If there is maladaptive plasticity as a result of immobility, prevention of the use of this device and promoting early active mobilization within the individual may be possibilities for treatment.

Regarding marital status, married individuals or those who had previously been married were more likely to have pain symptoms. Similar findings have been demonstrated elsewhere $^{23}$. While it is sometimes difficult to establish why this happens, it is possible that difficulties in living together could contribute to pain symptoms. This would be enhanced by the presence of a higher frequency of anxiety in patients with pain, which is a common finding ${ }^{24}$.

There was loss of quality of life in the items of SF-36 scale associated with pain and functional capacity in the pain group. In general, the quality of life in patients with peripheral nerve injury is worse than in normal patients and this also applies to functional capacity ${ }^{25}$. One previous study found different results when measuring quality of life in brachial plexus injury ${ }^{26}$. However, the instrument used for evaluation was different from that used in this study and in previous studies and their sample was small.

An evaluation of musculoskeletal sources of pain through a more detailed history and physical examination with pressure threshold measurements, range of motion tests, muscle strength and electromyographic signals could contribute to further information about the pain. Future research monitoring individuals during the follow-up phase is important for a better understanding of the evolution of pain and to understand the influence of pain on functional recovery of these patients. Because of the possibility that the pain is consequent to maladaptive plasticity in the brain, neuroimaging studies or electrophysiological tools are desirable.

This study presented some limitations: lack of information about types of drugs used for pain treatment; and mixed pain was not evaluated because the Douleur Neuropathique 4 was not created for this purpose. The Leeds Assessment of Neuropathic Symptoms and Signs could have been used but it was validated to Brazilian Portuguese only after the research project was submitted to the Institutional Review Board.

In conclusion, TBPI is more common in young male victims of motorcycle accidents who often suffer pain. Although TBPI involves a nerve injury, nociceptive pain may also occur and clear steps of pain classification, using validated instruments, are essential to avoid errors in diagnosis and treatment.

Acknowledgments: Laboratory of Functional Electrical, Institute of Heath Science - Federal University from Bahia; 
Deolindo Couto Neurology Institute - Federal University of Rio de Janeiro; Ambulatory Peripheral Nerve Lesions from the Psychiatric Institute, Clinical Hospital - Faculty of Medicine of São Paulo University; Lyn T Yeng; Ricardo Galhardoni; José M Siqueira; José FG Corrêa; Juliana Maia; Gustavo Pacheco; Claudia D Vargas ${ }^{5}$; José Marcos PF Lima; Israel Souza

\section{References}

1. Geertzen JH, Groothoff JW, Nicolai JP, Rietman JS. Brachial plexus neuropathy: a long-term outcome study. J Hand Surg Br. 2000; 25(5):461-4. doi:10.1054/jhsb.2000.0459

2. Novak BCB, Anastakis DJ, Beaton DE, Mackinnon SE, Katz J. Biomedical and psychosocial factors associated with disability after peripheral nerve injury. J Bone Joint Surg Am. 2011; 93(10):929-37. doi:10.2106/JBJS.J.00110

3. Privat JM, Allieu Y, Bonnel F, De Godebout J. [Pain following traumatic lesions of the brachial plexus (radicular avulsions and truncular lesions)]. Neurochirurgie. 1985;31(5):435-41. French.

4. Bruxelle J, Travers V, Thiebaut JB. Occurrence and treatment of pain after brachial plexus injury. Clin Orthop Relat Res. 1988;(237):87-95. doi:10.1097/00003086-198812000-00013

5. Ciaramitaro M, Mondelli M, Longullo F, Grimaldi F, Battiston B, Sard A et al. Traumatic peripheral nerve injuries: epidemiological findings, neuropathic pain and quality of life in 158 patients. J Peripher Nerv Syst. 2010;15(2):120-7. doi:10.1111/j.1529-8027.2010.00260.x

6. Flores LP. [Epidemiological study of the traumatic brachial plexus injuries in adults]. Arq Neuropsiquiatr. 2006;64(1):88-94. Portuguese. doi:10.1590/S0004-282X2006000100018

7. Jain DK, Bhardwaj P, Venkataramani H, Sabapathy SR. An epidemiological study of traumatic brachial plexus injury patients treated at an Indian centre. Indian J Plast Surg. 2012;45(3):498-503. doi:10.4103/0970-0358.105960

8. Kretschmer T, Ihle S, Antoniadis G, Seidel JA, Heinen C, Börm $W$ et al. Patient satisfaction and disability after brachial plexus surgery. Neurosurgery. 2009;65(4 Suppl):A189-96. doi:10.1227/01.NEU.0000335646.31980.33

9. Vannier J-L, Belkheyar Z, Oberlin C, Montravers P. [Management of neuropathic pain after brachial plexus injury in adult patients: a report of 60 cases]. Ann Fr Anesth Reanim. 2008;27(11):890-5. French. doi:10.1016/j.annfar.2008.08.013

10. Waikakul S, Waikakul W, Pausawasdi S. Brachial plexus injury and pain incidence and the effects of surgical reconstruction. J Med Assoc Thai. 2000;83(7):708-18.

11. Berman JS, Birch R, Anand P. Pain following human brachial plexus injury with spinal cord root avulsion and the effect of surgery. Pain. 1998;75(2-3):199-207. doi:10.1016/S0304-3959(97)00220-0

12. Brill S, Aryeh IG. Neuromodulation in the management of pain from brachial plexus injury. Pain Physician. 2008;11(1):81-5.

13. Dolan RT, Butler JS, Murphy SM, Hynes D, Cronin KJ. Health-related quality of life and functional outcomes following nerve transfers for traumatic upper brachial plexus injuries. J Hand Surg Eur Vol. 2012;37(7):642-51. doi:10.1177/1753193411432706
14. Santos JG, Brito JO, Andrade DC, Kaziyama VM, Ferreira KA, Souza I et al.. Translation to Portuguese and validation of the Douleur Neuropathique 4 questionnaire. J Pain. 2010;11(5):484-90. doi:10.1016/j.jpain.2009.09.014

15. Bouhassira D, Attal N, Alchaar H, Boureau F, Brochet B, Bruxelle $J$ et al. Comparison of pain syndromes associated with nervous or somatic lesions and development of a new neuropathic pain diagnostic questionnaire (DN4). Pain. 2005;114(1-2):29-36. doi:10.1016/j.pain.2004.12.010

16. Elm E, Altman DG, Egger M, Pocock SJ, Gøtzsche PC, Vandenbroucke JP. The Strengthening the Reporting of Observational Studies in Epidemiology (STROBE) statement: guidelines for reporting observational studies. Epidemiology. 2007;18(6):800-4. doi:10.1097/EDE.0b013e3181577654

17. Narakas $A O$. The effects on pain of reconstructive neurosurgery in 160 patients with traction and/or crush injury to the brachial plexus. In: Siegfried J, Zimmermann M, eds. Phantom and stump pain. Berlim: Springer; 1981. p. 126-47

18. Portal Brasil. Saúde. Brasil reduz em 5,7\% número de mortes no trânsito. Brasília, DF; 2015 [cited 2016 Jul 12]. Available from: http:// www.brasil.gov.br/saude/2015/11/brasil-reduz-em-5-7-numerode-mortes-no-transito

19. Moran SL, Steinmann SP, Shin AY. Adult brachial plexus injuries: mechanism, patterns of injury, and physical diagnosis. Hand Clin. 2005;21(1):13-24. doi:10.1016/j.hcl.2004.09.004

20. Htut M, Misra M, Anand P, Birch R, Carlstedt T. Pain phenomena and sensory recovery following brachial plexus avulsion injury and surgical repair. J Hand Surg Eur Vol. 2006;31B(6):596-605. doi:10.1016/j.jhsb.2006.04.027

21. Flor H, Nikolajsen L, Staehelin Jensen T. Phantom limb pain: a case of maladaptive CNS plasticity? Nat Rev Neurosci. 2006;7(11):873-81. doi:10.1038/nrn1991

22. Parry CB. Pain in avulsion lesions of the brachial plexus. Pain. 1980;9(1):41-53. doi:10.1016/0304-3959(80)90027-5

23. Novak CB. Rehabilitation following motor nerve transfers. Hand Clin. 2008;24(4):417-23. doi:10.1016/j.hcl.2008.06.001

24. Sá KN, Baptista AF, Matos MA, Lessa I. Chronic pain and gender in Salvador population, Brazil. Pain. 2008;139(3):498-506. doi:10.1016/j.pain.2008.06.008

25. Rocha G, Schor N. [Motorcycle accidents in the municipality of Rio Branco in the State of Acre: characterization and trends]. Ciênc Saúde Coletiva. 2013;18(3):721-32. Portuguese. doi:10.1590/S1413-81232013000300018

26. Choi PD, Novak CB, Mackinnon SE, Kline DG. Quality of life and functional outcome following brachial plexus injury. J Hand Surg Am. 1997;22(4):605-12. doi:10.1016/S0363-5023(97)80116-5 